\title{
DIGLOSIA
}

Volume 2, Nomor 1 (Februari 2019)

p-ISSN 2615-725X (Print)

Halaman $47-58$

e-ISSN 2615-8655 (Online)

\section{PENGEMBANGAN EVALUASI PEMBELAJARAN TEMATIK DENGAN MENGGUNAKAN RUBRIK KELAS IV DI GUGUS IV KECAMATAN SAMARINDA ULU}

\author{
Nurhayati ${ }^{1, *}$, Hardoko $^{2}$, dan Warman ${ }^{3}$ \\ ${ }^{1}$ Magister Manajemen Pendidikan (Konsentrasi PGSD), FKIP Universitas Mulawarman \\ ${ }^{2}$ Fakultas Keguruan dan Ilmu Pendidikan, Universitas Mulawarman \\ ${ }^{3}$ Fakultas Keguruan dan Ilmu Pendidikan, Universitas Mulawarman \\ *Pos-el korespondensi: jaynurhafidz@gmail.com
}

\begin{abstract}
This study aims to (1) find out the facts of learning in the field towards evaluating thematic learning using the grade IV elementary school rubric; (2) knowing the feasibility of evaluating thematic learning by using the rubric in grade IV elementary school students; (3) knowing the effectiveness of evaluating thematic learning by using the rubric in grade IV elementary school students. This research is a Research and Development $(\mathrm{R}$ \&D) study with a procedural model that adapts research procedures according to Borg and Gall which can be done in 10 stages (1) research and information collecting, (2) planning, (3) developing preliminary from products, (4) preliminary field testing, (5) main product revision, (6) playing field testing and (7) operational product revision, (8) operational field testing, (9) final product revision, (10) Dissemination and distribution. Evaluation development used is the rubric feasibility assessment sheet using a Likert scale which is made in the form of a checklist and teacher response questionnaire as well as a questionnaire for expert validation. The technical data analysis used in this study is qualitative and quantitative data. The results of this study are as follows. First, the fact of learning in the field towards the development of learning evaluations by using Rubrics after going through the introduction and experiment stages of evaluating students by using rubrics, the teacher who initially did not understand the rubric now understood the rubric. can be seen from the difference in the average pre-test and post-test, namely 52.2 and 88.06. Second, feasibility of Evaluation of Thematic Learning by using Rubric with 2 material expert Validator Tests of $94.28 \%$ and 2 education expert Validator tests of 95\%. Third, he effectiveness of evaluating thematic learning by using Rubrics in small group trials was $86.67 \%$, and large group tests were $85.04 \%$.
\end{abstract}

Keywords: learning evaluation, thematic learning, rubric

\begin{abstract}
ABSTRAK
Penelitian ini bertujuan untuk mengetahui (1) fakta pembelajaran di lapangan terhadap evaluasi pembelajaran tematik dengan menggunakan rubrik kelas IV Sekolah Dasar; (2) kelayakan evaluasi pembelajaran tematik dengan menggunakan rubrik pada siswa kelas IV Sekolah Dasar; dan (3) keefektifan evaluasi pembelajaran tematik dengan menggunakan rubrik pada siswa kelas IV Sekolah Dasar. Penelitian ini merupakan Research and Development $(R \Theta D)$ dengan model prosedural yang mengadaptasi prosedur penelitian menurut Borg and Gall yang dapat dilakukan dengan 10 tahapan, yaitu (1) research and information collecting, (2) planning, (3) develop preliminary from of product, (4) preliminary field testing, (5) main product revision, (6) main field testing, (7) operational product revision, (8) operational field testing, (9) final product revision,
\end{abstract}


(10) Dissemination and distribution. Pengembangan evaluasi yang digunakan adalah lembar penilaian kelayakan rubrik dengan menggunakan skala likert yang dibuat dalam bentuk checklist dan angket respons guru sama seperti angket untuk validasi ahli. Teknis analisis data yang digunakan pada penelitian ini data kualitatif dan kuantitatif. Hasil penelitian ini adalah sebagai berikut. Pertama, fakta pembelajaran di lapangan terhadap pengembangan evaluasi pembelajaran dengan menggunakan Rubrik setelah melalui tahapan pengenalan dan percobaan melakukan evaluasi kepada peserta didik dengan cara penilaian menggunakan rubrik, maka guru yang awalnya belum memahami tentang rubrik sekarang sudah paham tentang rubrik hal tersebut dapat dilihat dari perbedaan rata-rata pretes dan postes, yaitu 52,2 dan 88,06. Kedua, kelayakan Evaluasi Pembelajaran Tematik dengan menggunakan Rubrik dengan 2 Uji Validator ahli materi sebesar 94,28\% dan 2 uji Validator ahli pendidikan sebesar 95\%. Ketiga, keefektifan evaluasi pembelajaran tematik dengan menggunakan Rubrik pada uji coba kelompok kecil sebesar 86,67\%, dan uji kelompok besar sebesar 85,04\%.

Kata Kunci: evaluasi pembelajaran, pembelajaran tematik, rubrik

\section{A. PENDAHULUAN}

Pendidikan adalah sebagai usaha sadar dan terencana untuk mewujudkan suasana belajar dan proses pembelajaran untuk peserta didik secara aktif mengembangkan potensi dirinya untuk memiliki kekuatan spiritual keagamaan, pengendalian diri, kepribadian, kecerdasan, akhlak mulia, serta keterampilan yang diperlukan dirinya dan masyarakat. Salah satu hal yang tak bisa terlepaskan dalam bidang pendidikan adalah hasil belajar. Hasil belajar yang diperoleh peserta didik sangat mempengaruhi keberhasilan dari tujuan pembelajaran. Hasil belajar dapat menjadi salah satu tolak ukur keberhasilan seorang guru dalam melaksanakan kegiatan belajar mengajar (Zulkardi dalam Aryani, 2001).

Dalam perjalanan sejarah sejak tahun 1945, kurikulum pendidikan nasional telah mengalami perubahan, yaitu pada tahun 1947, 1952, 1964, 1965, 1975, 1984, 2004, 2006, 1994, 2006, dan yang saat ini digunakan adalah 2013 atau sering disebut kurikulum 2013. Transformasi ini merupakan konsekuesi logis dari terjadinya sistem perubahan politik, sosial, budaya, ekonomi, dan iptek dalam masyarakat, berbangsa, dan bernegara. Sebab, kurikulum sebagai seperangkat rencana pendidikan perlu dikembangkan secara dinamis sesuai dengan tuntutan dan perubahan yang terjadi di masyarakat (Hidayat, 2013:11).

Penilaian adalah suatu kegiatan untuk memberikan berbagai informasi secara berkesinambungan dan menyeluruh tentang proses dan hasil yang telah dicapai peserta didik (Arifin, 2017). Semua kegiatan pembelajaran yang dilakukan harus selalu diikuti atau disertai dengan kegiatan penilaian.

Penilaian bertujuan untuk membantu peserta didik mengidentifikasi dan mengetahui kesulitan-kesulitan yang mereka hadapi dalam kegiatan belajar. Salah satu prinsip penilaian adalah menyeluruh dan berkesinambungan, dengan demikian guru harus menggunakan berbagai teknik penilaian yang sesuai dan mencakup semua aspek kompetensi untuk memantau perkembangan kemampuan peserta didik. Aspek kompetensi yang dimaksud adalah aspek kognitif (pengetahuan), aspek psikomotor (keterampilan), dan aspek afektif (sikap). Untuk menilai ketiga aspek tersebut pada peserta didik, salah satu instrumen penilaian yang digunakan adalah rubrik.

Rubrik merupakan panduan penilaian yang menggambarkan kriteria yang diinginkan guru dalam menilai atau 
memberi tingkatan dari hasil pekerjaan peserta didik. Rubrik adalah pedoman penskoran yang digunakan untuk menilai unjuk kerja peserta didik berdasarkan jumlah skor dari beberapa kriteria dan tidak hanya menggunakan satu skor saja (Majid, 2014).

Tujuan dari penilaian rubrik yaitu guru diharapkan secara jelas memahami dasar penilaian yang akan digunakan untuk mengukur suatu kinerja peserta didik. Kedua pihak (guru dan peserta didik) akan mempunyai pedoman bersama yang jelas tentang tuntutan kinerja yang diharapkan. Rubrik diharapkan pula dapat menjadi pendorong atau motivator bagi peserta didik dalam proses pembelajaran.

Kekuatan dari evaluasi dengan menggunakan rubrik, antara lain: (1) rubrik dapat menjelaskan deskripsi tugas; (2) rubrik memberikan informasi bobot penilaian, peserta didik memperoleh umpan balik yang cepat dan akurat; (3) penilaian lebih objektif dan konsisten, peserta didik akan menjadi pembelajar yang aktif, para peserta didik memperoleh content knowledge dan procedural knowledge, para peserta didik dapat menilai kinerja kelompoknya sendiri. Dalam upaya menentukan tingkat ketercapaian kompetensi peserta didik yang mengacu pada pembentukan karakter siswa diperlukan rubrik penilaian sebagai pedoman dalam penilaian sikap, penilaian pengetahuan dan keterampilan siswa.

Berdasarkan observasi dan wawancara di lapangan dengan guru yang ada di SDN Gugus IV Kecamatan Samarinda Ulu ternyata mereka belum memahami tentang penilaian dengan menggunakan rubrik, hal ini disebabkan karena Penilaian di sekolah masih terbatas yaitu hanya untuk soal-soal yang berkaitan dengan ilmu pengetahuan (kognitif) sesuai dengan pedoman kurikulum tingkat satuan pendidikan. Sehingga pada saat pemerintah mewajibkan setiap sekolah untuk menggunakan kurikulum 2013 maka timbullah sebuah permasalahan baru bagi seorang guru untuk memberikan penilaian pembelajaran kepada peserta didik yang disesuaikan dengan pedoman kurikulum 2013.

Penelitian ini akan mencoba memberikan evaluasi berupa penilaian pembelajaran kepada peserta didik dengan menggunakan rubrik, karena pedoman penilaian dalam kurikulum 2013 yang terdapat pada buku guru tema enam citacitaku, penilaian yang digunakan adalah penilaian rubrik. Penulis akan mengenalkan rubrik kepada guru di SD Gugus IV Kecamatan Samarinda Ulu, agar mereka memahami sebuah evaluasi pembelajaran dengan menggunakan rubrik.

Tujuan penelitian ini adalah (1) mengetahui fakta pembelajaran di lapangan terhadap evaluasi pembelajaran dengan menggunakan rubrik pada siswa kelas IV Sekolah Dasar; (2) mengetahui kelayakan evaluasi pembelajaran tematik dengan menggunakan rubrik pada siswa kelas IV Sekolah Dasar; dan (3) mengetahui keefektifan evaluasi pembelajaran tematik dengan menggunakan rubrik pada siswa kelas IV Sekolah Dasar.

\section{B. LANDASAN TEORI}

\section{Pembelajaran}

Belajar pada hakikatnya merupakan proses perubahan di dalam kepribadian yang berupa kecakapan, sikap, kebiasaan, dan kepandaian. Perubahan ini bersifat menetap dalam tingkah laku yang terjadi sebagai suatu hasil dari latihan atau pengalaman (Majid, 2014). Belajar merupakan kegiatan berproses dan merupakan unsur yang sangat fundamental dalam setiap jenjang pendidikan. Dalam proses belajar akan menimbulkan keterampilan-keterampilan yang dimiliki oleh peserta didik. Keterampilan-keterampilan belajar menurut Fogarty (dalam Wangid, Mustadi, Erviana, \& Arifin, 2014) meliputi keterampilan berpikir (thinking skill), 
keterampilan sosial (social skill), dan keterampilan mengorganisir (organizing skill).

Pembelajaran dapat diartikan suatu proses atau cara yang dilakukan seseorang dapat melakukan kegiatan belajar. Istilah pembelajaran (instruction) berbeda dengan istilah pengajaran (teaching). Kata pengajaran lebih bersifat formal dan hanya ada dalam konteks guru dengan peserta didik di kelas/sekolah, sedangkan kata pembelajaran tidak hanya ada dalam konteks guru dengan peserta didik dikelas secara formal, akan tetapi juga meliputi kegiatan-kegiatan belajar peserta didik di luar kelas yang mungkin saja tidak dihadiri oleh guru secara fisik. Pada hakikatnya pembelajaran adalah proses interaksi antara peserta didik dengan lingkungannya sehingga terjadi perubahan ke arah yang lebih baik. Pembelajaran merupakan perpaduan dari dua aktivitas, yaitu aktivitas mengajar dan belajar. Aktivitas mengajar menyangkut peranan seorang guru dalam konteks mengupayakan terciptanya jalinan komunikasi harmonis antara mengajar itu sendiri dengan belajar.

Pembelajaran dapat diartikan sebagai suatu proses atau cara yang dilakukan agar seseorang dapat melakukan kegiatan belajar. Dalam suatu melaksanakan proses pembelajaran diperlukan suatu program. Ciri suatu program dari pembelajaran adalah sistematik, sistemis, dan terencana. Sistematik artinya keteraturan, dalam hal ini pembelajaran harus dilakukan dengan urutan langkah-langkah tertentu, mulai dari perencanaan, pelaksanaan sampai dengan penilaian. penilaian merupakan salah satu komponen pokok dalam proses pembelajaran. Teknik penilaian dalam pembelajaran terus berkembang, dengan harapan dapat meningkatkan kualitas pembelajaran. Teknik penilaian yang digunakan harus disesuaikan dengan karakteristik indikator, standar kompetensi dan kompetensi dasar (Purnamasari, 2015). Setiap langkah harus bersyarat, langkah pertama merupakan syarat untuk masuk langkah yang kedua, langkah kedua merupakan syarat untuk masuk langkah yang ketiga, dan seterusnya (Arifin, 2017).

\section{Pembelajaran Tematik Kurikulum 2013}

Pembelajaran Tematik adalah pembelajaran yang menggunakan tema untuk mengaitkan beberapa mata pelajaran sehingga dapat memberikan pengalaman bermakna kepada peserta didik. Pembelajaran tematik lebih menekankan pada keterlibatan peserta didik dalam proses belajar secara aktif dalam proses pembelajaran. Oleh karena itu, peserta didik dapat memperoleh pengalaman langsung dan terlatih untuk dapat menemukan sendiri berbagai pengetahuan yang dipelajarinya. Melalui pengalaman langsung, peserta didik akan memahami konsep-konsep yang mereka pelajari dan menghubungkannya dengan konsep lain yang telah dipahaminya.

Pembelajaran tematik berfungsi untuk memberikan kemudahan bagi peserta didik dalam memahami dan mendalami konsep materi yang tergabung dalam tema serta dapat menambah semangat belajar karena materi yang dipelajari merupakan materi yang nyata dan bermakna bagi peserta didik agar memiliki pengalaman belajar dalam 5M, yakni mengamati, menanya, mencari informasi, mengasosiasi, dan mengkomunikasikan apa yang mereka peroleh atau mereka ketahui setelah menerima materi.

Tujuan pembelajaran tematik adalah mudah memusatkan perhatian pada suatu tema atau topik tertentu, mempelajari pengetahuan dan mengembangkan berbagai kompetensi muatan pembelajaran dalam tema sama, memiliki pemahaman terhadap materi pelajaran lebih mendalam, mengembangkan kompetensi berbahasa lebih baik, lebih semangat belajar karena dapat berkomunikasi dalam situasi nyata, Lebih merasakan manfaat dan makna belajar, 
guru dapat menghemat waktu, budi pekerti dan moral peserta didik dapat ditumbuh kembangkan dengan mengangkat nilai budi pekerti sesuai dengan situasi dan kondisi.

Sebagai suatu model pembelajaran di sekolah dasar, pembelajaran tematik memiliki karakteristik yaitu berpusat pada peserta didik, memberikan pengalaman langsung, pemisahan mata pelajaran tidak begitu jelas, menyajikan konsep dari berbagai mata pelajaran, dan bersifat fleksibel. Karakteristik pembelajaran tematik adalah holistik, bermakna, autentik dan aktif.

\section{Evaluasi Pembelajaran}

Evaluasi merupakan kumpulan sebuah data untuk menentukan sejauh mana, dalam hal apa, dan bagaimana tujuan pendidikan dapat tercapai, jika belum apa sebabnya (Arikunto, 2005). evaluasi adalah suatu proses untuk menggambarkan peserta didik dan menimbangnya dari segi nilai tetapi juga arti atau makna. Berdasarkan pengertian ini, evaluasi adalah suatu proses bukan suatu hasil (produk). Hasil yang diperoleh dari kegiatan evaluasi adalah kualitas sesuatu, baik yang menyangkut tentang nilai atau arti, sedangkan kegiatan untuk sampai pada pemberian nilai dan arti itu adalah evaluasi. Membahas tentang evaluasi berarti mempelajari bagaimana proses pemberian pertimbangan mengenai kualitas sesuatu. Gambaran kualitas yang dimaksud merupakan konsekuensi logis dari proses evaluasi yang dilakukan. Proses tersebut tentu dilakukan secara sistematis dan berkelanjutan, dalam arti terencana, sesuai dengan prosedur dan prinsip serta dilakukan secara terus-menerus.

Sedangkan penilaian merupakan suatu kegiatan yang tidak mungkin dipisahkan dari kegiatan pembelajaran secara umum. Semua kegiatan pembelajaran yang dilakukan harus selalu diikuti atau disertai dengan kegiatan penilaian. Kiranya merupakan suatu hal yang tidak lazim jika terjadi adanya kegiatan pembelajaran yang dilakukan seorang guru di kelas tanpa pernah diikuti oleh adanya suatu penilaian. Tanpa mengadakan suatu penilaian, kita tidak mungkin dapat menilai dan melaporkan hasil pembelajaran peserta didik secara objektif (Nurgiyantoro, 2012).

Menurut Peraturan Menteri dan Kebudayaan Republik Indonesia nomor 23 tahun 2016 tentang Standar Penilaian Pendidikan pasal 1 ayat 1 menyebutkan tentang standar penilaian adalah kriteria mengenai lingkup, tujuan, manfaat, prinsip, mekanisme, prosedur, dan instrumen penilaian hasil belajar peserta didik yang digunakan sebagai dasar dalam penilaian hasil belajar peserta didik pada pendidikan dasar dan pendidikan menengah. Pasal 2 menyebutkan bahwa Penilaian adalah proses pengumpulan dan pengolahan informasi untuk mengukur pencapaian hasil belajar peserta didik. Pasal 3 menyebutkan bahwa Pembelajaran adalah proses interaksi antar peserta didik, antara peserta didik dengan pendidik dan sumber belajar pada suatu lingkungan belajar.

Mekanisme penilaian hasil belajar oleh pendidik meliputi perancangan strategi penilaian oleh pendidik dilakukan pada saat penyusunan rencana pelaksanaan pembelajaran (RPP) berdasarkan silabus, penilaian aspek sikap dilakukan melalui observasi/pengamatan dan teknik penilaian lain yang relevan, dan pelaporannya menjadi tanggung jawab wali kelas atau guru kelas, penilaian aspek pengetahuan dilakukan melalui tes tertulis, tes lisan, dan penugasan sesuai dengan kompetensi yang dinilai, penilaian keterampilan dilakukan melalui praktik, produk, proyek, portofolio, dan/atau teknik lain sesuai dengan kompetensi yang dinilai, peserta didik yang belum mencapai KKM satuan pendidikan harus mengikuti pembelajaran remedi, hasil penilaian pencapaian pengetahuan dan keterampilan peserta didik disampaikan dalam bentuk 
angka dan/atau deskripsi, jadi dalam kurikulum 2013 hasil penilaian pencapaian pengetahuan harus dibuat dalam bentuk deskripsi, berbeda dengan Kurikulum sebelumnya yang ditampilkan hanya berupa angka. Oleh sebab itu seorang guru harus lebih memahami dan mengenal penilaian dengan menggunakan rubrik, karena dalam rubrik tersebut berisi kriteria atau deskripsi tentang hasil peserta didik.

\section{Rubrik Penilaian}

Sebuah penilaian pada dasarnya memiliki sebuah kriteria penilaian yang disebut rubrik (Rustaman, 2006). Rubrik merupakan panduan asesmen yang menggambarkan kriteria penilaian yang digunakan guru dalam menilai atau memberi tingkatan hasil pekerjaan siswa (Centre for Teaching and Learning, 2014; Yusuf, 2015). Rubrik merupakan panduan asesmen yang menggambarkan kriteria yang digunakan guru dalam menilai atau memberi tingkatan dari hasil pekerjaan siswa (Eshun \& Osei-poku, 2013). Rubrik perlu memuat daftar karakteristik yang diinginkan yang perlu ditunjukkan dalam suatu pekerjaan siswa disertai dengan panduan untuk mengevaluasi masingmasing karakteristik tersebut. Rubrik adalah pedoman penskoran yang digunakan untuk menilai unjuk kerja siswa berdasarkan jumlah skor dari beberapa kriteria dan tidak hanya menggunakan satu skor saja.

$$
\text { Dalam Rencana Perangkat }
$$

Pembelajaran (RPP) kurikulum 2013 di jelaskan bahwa pembelajaran tematik pada Tema 6 "Cita-Citaku" Subtema 1 "Hebatnya Cita-Citaku" terdapat kompetensi inti, kompetensi dasar, tujuan, materi pembelajaran, materi, kegiatan pembelajaran, materi, pendekatan metode, kegiatan pembelajaran, sumber dan media, dan penilaian.

Berikut ini dipaparkan isi dari Tema 6 Subtema 1 tersebut.

\section{a. Kompetensi Inti}

1. Menerima dan menjalankan ajaran agama yang dianutnya.

2. Menunjukkan perilaku jujur, disiplin, tanggung jawab, santun, peduli, dan percaya diri dalam berinteraksi dengan keluarga, teman, guru dan tetangga.

3. Memahami pengetahuan faktual dengan cara mengamati (mendengar, melihat, membaca) dan menanya berdasarkan rasa ingin tahu tentang dirinya, makhluk ciptaan Tuhan dan kegiatannya, dan benda-benda yang dijumpainya di rumah dan di sekolah.

4. Menyajikan pengetahuan faktual dalam bahasa yang jelas, sistematis dan logis, dalam karya yang estetis, dalam gerakan yang mencerminkan anak sehat, dan dalam tindakan yang mencerminkan perilaku anak beriman dan berakhlak mulia

\section{b. Kompetensi Dasar}

Muatan: Bahasa Indonesia

Tabel 1. Kompetensi Dasar Muatan Bahasa Indonesia

\begin{tabular}{|l|l|}
\hline No & Kompetensi Dasar \\
\hline 3.6 & $\begin{array}{l}\text { Menggali isi dan amanat puisi yang di sajikan } \\
\text { secara lisan dan tulis dengan tujuan untuk } \\
\text { kesenangan }\end{array}$ \\
\hline 4.6 & $\begin{array}{l}\text { Melisankan puisi hasil karya pribadi dengan } \\
\text { lafal, intonasi, dan ekspresi yang tepat } \\
\text { sebagai bentuk ungkapan diri }\end{array}$ \\
\hline
\end{tabular}

Muatan: Ilmu Pengetahuan Alam

Tabel 2. Kompetensi Dasar Muatan Ilmu Pengetahuan Alam

\begin{tabular}{|l|l|}
\hline No & Kompetensi Dasar \\
\hline 3.2 & $\begin{array}{l}\text { Membandingkan siklus hidup beberapa } \\
\text { jenis makhluk hidup serta mengaitkan } \\
\text { dengan upaya pelestariannya }\end{array}$ \\
\hline 4.6 & $\begin{array}{l}\text { Membuat skema siklus hidup beberapa jenis } \\
\text { makhluk hidup yang ada di lingkungan } \\
\text { sekitarnya, dan slogan upaya pelestariannya. }\end{array}$ \\
\hline
\end{tabular}




\section{c. Tujuan}

1. Peserta didik dapat menjelaskan cara membuat puisi dengan benar.

2. Peserta didik dapat membuat puisi secara mandiri dengan baik.

3. Siswa dapat membedakan dua daur hidup binatang dengan cermat.

4. Dengan membandingkan siklus hidup makhluk hidup yang berbeda siswa dapat melaporkannya dengan tepat.

\section{d. Materi}

1. Cara membuat puisi

2. Daur hidup makhluk hidup

\section{e. Pendekatan dan Metode}

Pendekatan : Scientific

Strategi : Cooperative Learning

Model : Example dan Non-Example

Metode : Penugasan, pengamatan, tanya jawab, diskusi, dan ceramah

\section{f. Kegiatan Pembelajaran}

Terdapat pada lampiran III.

\section{g. Sumber dan Media}

1. Buku pedoman Guru tema 6 kelas 4 dan Buku siswa Tema 6 kelas 4 (Buku Tematik terpadu kurikulum 2013, Jakarta Kementerian Pendidikan dan Kebudayaan, 2017)

2. Buku Sekolahnya Manusia, Munif Chatib

3. Video/slide

4. Gambar metamorfosis

5. Teks/puisi

6. Majalah/koran anak

7. Lingkungan Sekitar

\section{h. Penilaian}

Penilaian terhadap proses dan hasil pembelajaran dilakukan oleh guru untuk mengukur tingkat pencapaian kompetensi peserta didik. Hasil penilaian digunakan guru sebagai bahan penyusunan laporan kemajuan hasil belajar dan memperbaiki proses pembelajaran. Menurut Kementerian Pendidikan dan Kebudayaan
Direktorat Jenderal Pendidikan Dasar Dan Menengah Direktorat Pembinaan Sekolah Dasar Tahun 2017. Penilaian terhadap materi ini dapat dilakukan sesuai kebutuhan guru yaitu dari pengamatan sikap, pengetahuan, dan presentasi unjuk kerja atau hasil kerja dengan menggunakan Rubrik.

1. Penilaian sikap

Nilai utama karakter pada Sikap Spiritual (KI-1), yaitu:

1.1 Religiositas, diantaranya: beriman dan bertaqwa kepada Tuhan Yang Maha Esa, taat beribadah, bersyukur, berdoa sebelum dan sesudah melakukan kegiatan, dll.

1.2 Integritas, diantaranya: jujur, rendah hati, santun, tanggung jawab, keteladanan, komitmen moral, cinta kebenaran, menepati janji, anti korupsi, dll.

2. Penilaian Sosial

Nilai utama karakter pada Sikap Sosial (KI-2), yaitu:

2.1 Nasionalisme, diantaranya: cinta tanah air, semangat kebangsaan, menghargai kebinekaan, menghayati lagu nasional dan lagu daerah, cinta produk Indonesia, cinta damai, rela berkorban, taat hukum, dll.

2.2 Kemandirian, diantaranya: disiplin, percaya diri, rasa ingin tahu, tangguh, bekerja keras, mandiri, kreatifinovatif, pembelajar sepanjang hayat, dll.

2.3 Gotong royong, diantaranya: suka menolong, bekerja sama, peduli sesama, peduli lingkungan, kebersihan dan kerapian, kekeluargaan, aktif dalam kegiatan kemasyarakatan, dll.

2.4 Integritas, diantaranya: jujur, rendah hati, santun, tanggung jawab, keteladanan, komitmen moral, cinta kebenaran, menepati janji, anti korupsi, dll. 
3. Penilaian Pengetahuan

Penilaian pengetahuan terdiri dari, tes tertulis, tes lisan, dan penugasan. Adapun bentuk dari tes tertulis adalah pilihan ganda, benar-salah, menjodohkan, isian/melengkapi, dan uraian. Bentuk dari tes lisan adalah perintah, kuis, dan tanya jawab. Bentuk dari tes penugasan adalah tugas yang dilakukan secara individu atau kelompok di sekolah, di luar sekolah, dan di rumah.

\section{Penilaian Keterampilan}

Penilaian keterampilan terdiri dari penilaian praktik, penilaian produk, dan penilaian proyek. Seorang guru dapat memilih salah satu bentuk dari penilaian keterampilan disesuaikan dengan materi yang diajarkan.

\section{METODE PENELITIAN}

Jenis yang digunakan dalam penelitian ini adalah metode penelitian dan pengembangan atau Research and Development. Menurut Borg \& Gall (2003) (dalam Sugiyono, 2017), secara umum, prosedur pengembangan produk dapat dilihat pada skema berikut.
Pada penelitian dan pengembangan ini, jenis data yang akan dihasilkan berupa data kualitatif dan kuantitatif. Instrumen yang digunakan untuk mengumpulkan data dalam uji coba penelitian ini adalah (1) lembar angket kebutuhan (2) lembar validasi ahli, dan (3) lembar angket respons guru.

Analisis data yang digunakan terdiri dari dua teknik yaitu teknik analisis deskriptif kualitatif untuk mengolah data hasil reviu ahli materi dan ahli pembelajar dengan mengelompokkan informasiinformasi dari data kualitatif berupa masukkan, kritik dan saran perbaikan yang terdapat pada angket dan hasil wawancara. Data kuantitatif diperoleh dari lembar kuesioner ahli materi dan ahli pembelajar selanjutnya dikonversi menjadi data kualitatif dengan konversi skala lima.

Adapun rumus yang digunakan untuk menghitung persentase adalah sebagai berikut.

Persentase $=\frac{\sum(\text { jawaban } \mathrm{x} \text { bobot tiap pilihan })}{\mathrm{n} \times \text { bobot tertinggi }} \times 100 \%$

Keterangan :

$\Sigma=$ jumlah

$\mathrm{n}=$ jumlah seluruh item angket

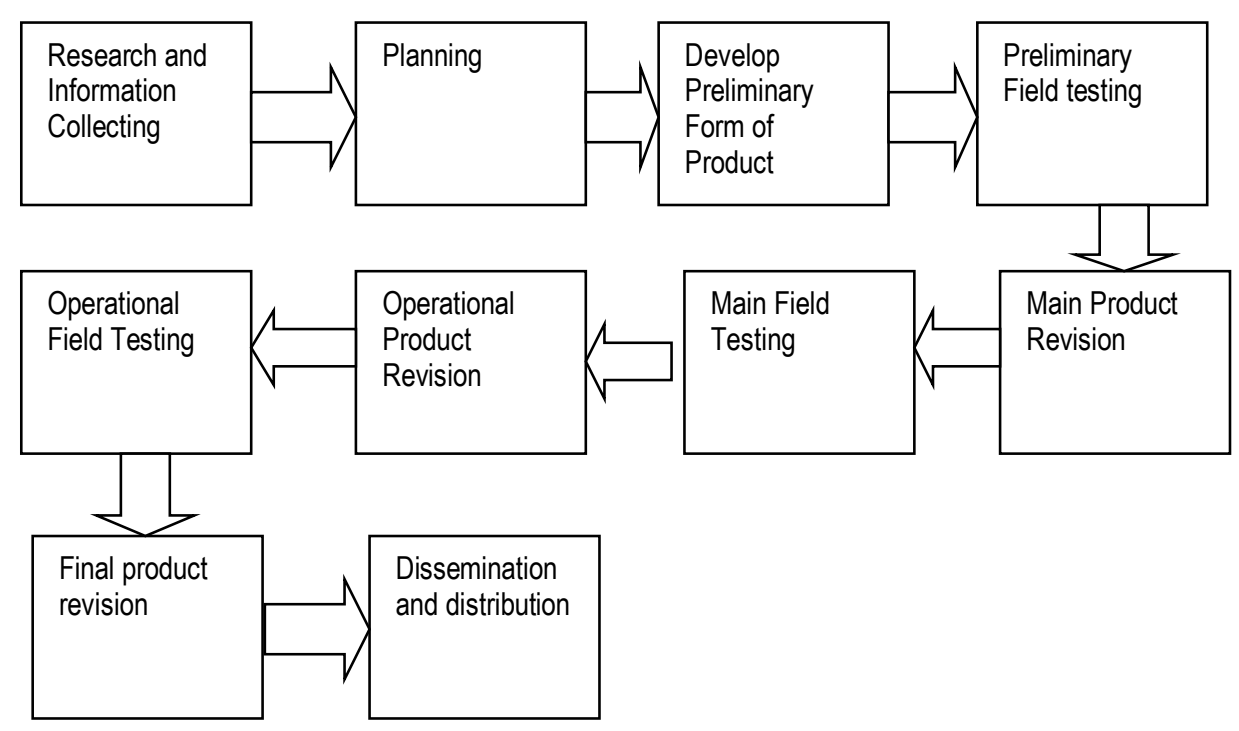

Gambar 1. Skema Prosedur Penelitian Pengembangan 
Tabel 3. Konversi tingkat pencapaian dengan skala lima (Purwanto, 2013).

\begin{tabular}{|c|c|c|c|}
\hline $\begin{array}{c}\text { Skala } \\
\text { Likert }\end{array}$ & Persentse & Kategori & Keputusan \\
\hline 1 & $0 \%-54 \%$ & $\begin{array}{l}\text { Sangat } \\
\text { kurang } \\
\text { layak }\end{array}$ & $\begin{array}{l}\text { Produk gagal, } \\
\text { revisi total isi } \\
\text { produk }\end{array}$ \\
\hline 2 & $55 \%-59 \%$ & $\begin{array}{l}\text { Kurang } \\
\text { layak }\end{array}$ & $\begin{array}{l}\text { Revisi dengan } \\
\text { meneliti } \\
\text { kembali bagian } \\
\text { yang kurang } \\
\text { baik }\end{array}$ \\
\hline 3 & $60 \%-75 \%$ & $\begin{array}{l}\text { Cukup } \\
\text { layak }\end{array}$ & $\begin{array}{l}\text { Produk dapat } \\
\text { dipakai dengan } \\
\text { merevisi } \\
\text { bagian yang } \\
\text { merupakan } \\
\text { kelemahan }\end{array}$ \\
\hline 4 & $76 \%-85 \%$ & $\begin{array}{l}\text { Baik / } \\
\text { layak }\end{array}$ & $\begin{array}{l}\text { Produk dapat } \\
\text { dilanjutkan } \\
\text { dan } \\
\text { menambahkan } \\
\text { hal-hal yang } \\
\text { dianggap } \\
\text { kurang }\end{array}$ \\
\hline 5 & $86 \%-100 \%$ & $\begin{array}{l}\text { Sangat } \\
\text { Layak }\end{array}$ & $\begin{array}{l}\text { Produk siap } \\
\text { dipakai di } \\
\text { lapangan tanpa } \\
\text { direvisi }\end{array}$ \\
\hline
\end{tabular}

Setelah mengetahui kelayakan produk yang dibuat, maka selanjutnya dilakukan uji produk. Uji produk dilakukan kepada guru melalui uji kelompok kecil dan uji kelompok besar. Hasil uji produk tersebut dibuat untuk mengetahui apakah produk yang dibuat efektif untuk digunakan.

\section{HASIL DAN PEMBAHASAN}

Produk yang dihasilkan dalam penelitian ini adalah berupa evaluasi pembelajaran tematik dengan menggunakan rubrik.

\section{Fakta Pembelajaran di Lapangan}

Berdasarkan hasil wawancara yang telah dilakukan dalam pengembangan evaluasi pembelajaran tematik kelas IV di Gugus IV Kecamatan Samarinda Ulu dapat diketahui 50\% guru di Gugus IV Kecamatan Samarinda Ulu belum memahami cara penilaian dengan menggunakan rubrik. Untuk mengetahui pemahaman tentang rubrik maka penulis melakukan pretes. Setelah melakukan pretes ternyata nilai pengetahuan tentang rubrik rata-ratanya 52,26. Oleh sebab itu, penulis mengadakan pelatihan terhadap guru-guru untuk menjelaskan dan mengenalkan penilaian dengan menggunakan rubrik. Setelah itu diadakan postes kembali dan nilai rata-ratanya sebesar 88,06. Dari hasil tersebut dapat diketahui bahwa guru sudah memahami tentang rubrik.

Tabel 4. Hasil Pretes dan Postes

\begin{tabular}{|c|c|}
\hline \multicolumn{2}{|c|}{ Nilai Rata-Rata } \\
\hline Pretes (X1) & Postest (X2) \\
\hline 52,26 & 88,06 \\
\hline
\end{tabular}

\section{Kelayakan Evaluasi Pembelajaran Tematik dengan Menggunakan Rubrik \\ Untuk mengetahui kelayakan evaluasi} pembelajaran tematik dengan menggunakan rubrik, maka penulis melakukan uji validasi terhadap rubrik yang dibuat kepada dua orang dosen ahli materi dan dua orang guru ahli pendidikan.

\section{Tabel 5. Hasil Validasi Ahli Materi}

\begin{tabular}{|l|c|c|}
\cline { 2 - 3 } \multicolumn{1}{c|}{} & \multicolumn{2}{c|}{ Skor } \\
\cline { 2 - 3 } \multicolumn{1}{c|}{} & X1 & X2 \\
\hline Jumlah & 65 & 67 \\
\hline Skor Total & \multicolumn{2}{|c|}{132} \\
\hline Skor Maksimal & \multicolumn{2}{|c|}{140} \\
\hline
\end{tabular}

$$
\begin{aligned}
\text { Persentase } & =\frac{\Sigma(\text { skor total })}{\mathrm{n} \times \text { bobot tertinggi }} \times 100 \% \\
& =\frac{132}{140} \times 100 \\
& =94,28 \%
\end{aligned}
$$


Tabel 6. Hasil Validasi Ahli Pendidikan

\begin{tabular}{|l|c|c|}
\cline { 2 - 3 } \multicolumn{1}{c|}{} & \multicolumn{2}{c|}{ Skor } \\
\cline { 2 - 3 } \multicolumn{1}{c|}{} & X1 & X2 \\
\hline Jumlah & 66 & 67 \\
\hline Skor Total & \multicolumn{2}{|c|}{133} \\
\hline Skor Maksimal & \multicolumn{2}{|c|}{140} \\
\hline
\end{tabular}

$$
\begin{aligned}
\text { Persentase } & =\frac{\Sigma(\text { skor total })}{\mathrm{n} \times \text { bobot tertinggi }} \times 100 \% \\
& =\frac{133}{140} \times 100 \\
& =95 \%
\end{aligned}
$$

Berdasarkan data kuantitatif dari ahli materi sebesar $94,28 \%$ dan ahli pendidikan sebesar 95\%, maka produk yang dibuat layak untuk digunakan tanpa revisi.

\section{Tabel 7. Reviu Ahli Materi}

\begin{tabular}{|l|l|}
\hline Kode & \multicolumn{2}{|c|}{ Komentar atau Saran } \\
\hline X1 & $\begin{array}{l}\text { Harus diperhatikan dalam Pembuatan } \\
\text { penilaian harus disesuaikan dengan aturan } \\
\text { yang ada }\end{array}$ \\
\hline X2 & $\begin{array}{l}\text { Dalam Pedoman Rubrik penilaian sikap } \\
\text { sosial predikat cukup jangan } \\
\text { menggunakan kata jarang tetapi harus } \\
\text { menggunakan kata kadang-kadang } \\
\text { sedangkan perlu pendampingan } \\
\text { menggunakan kata tidak pernah } \\
\text { melakukan perbuatan baik. }\end{array}$ \\
\hline
\end{tabular}

Tabel 8. Reviu Ahli Pendidikan

\begin{tabular}{|l|l|}
\hline Kode & \multicolumn{1}{|c|}{ Komentar atau Saran } \\
\hline X1 & $\begin{array}{l}\text { Rubrik yang dibuat sudah sesuai } \\
\text { dengan standar isi. }\end{array}$ \\
\hline X2 & $\begin{array}{l}\text { Rubrik yang dibuat sesuai dengan } \\
\text { kebutuhan guru inginkan dan penilaian } \\
\text { yang dibuat tidak terlalu rumit. }\end{array}$ \\
\hline
\end{tabular}

Berdasarkan data kualitatif yang diperoleh dari saran/komentar ahli materi pada Tabel 7, perlu dilakukan perbaikan dalam pedoman rubrik untuk menilai sikap sosial, yaitu pada skor 3, tidak boleh menggunakan kata jarang yang layak digunakan adalah kata kadang-kadang; dan pada skor 1 penulis menggunakan frasa pernah tidak, seharusnya yang digunakan adalah frasa tidak pernah. Saran-saran perbaikan dari ahli materi dijadikan sebagai bahan pertimbangan penulis untuk menyempurnakan produk pengembangan yang dihasilkan. Sedangkan berdasarkan data kualitatif yang diperoleh dari saran/komentar para ahli pendidikan pada Tabel 8 dikatakan bahwa pedoman rubrik yang dibuat sangat bagus dan menurut mereka tidak terlalu rumit dalam melakukan penilaian.

\section{Keefektifan Evaluasi Pembela- jaran Tematik dengan menggunakan Rubrik}

a. Uji coba kelompok kecil (small group evaluation)

Produk pengembangan evaluasi pembelajaran tematik dengan menggunakan rubrik yang di serahkan pada uji kelompok kecil yang diwakili oleh enam responden.

Tabel 9. Hasil Uji Kelompok Kecil

\begin{tabular}{|l|c|c|c|c|c|c|}
\cline { 2 - 7 } \multicolumn{1}{c|}{} & \multicolumn{6}{c|}{ Skor } \\
\cline { 2 - 7 } \multicolumn{1}{c|}{} & X1 & X2 & X3 & X4 & X5 & X6 \\
\hline Total & 42 & 36 & 40 & 36 & 44 & 33 \\
\hline $\begin{array}{l}\text { Skor } \\
\text { Total }\end{array}$ & \multicolumn{5}{|c|}{234} \\
\hline $\begin{array}{l}\text { Skor } \\
\text { Maksimal }\end{array}$ & \multicolumn{5}{|c|}{270} \\
\hline
\end{tabular}

$$
\begin{aligned}
\text { Persentase } & =\frac{\Sigma(\text { skor total })}{\mathrm{n} \times \text { bobot tertinggi }} \times 100 \% \\
& =\frac{234}{270} \times 100 \\
& =86,67 \%
\end{aligned}
$$

Hasil perhitungan di atas menunjukkan persentase sebesar $86,67 \%$ setelah dikualifikasi sangat valid sehingga evaluasi pembelajaran dengan menggunakan rubrik efektif untuk digunakan.

\section{b. Uji Coba Lapangan}

Uji coba lapangan pada lima belas guru di Gugus IV Kecamatan Samarinda 
Ulu, diperoleh hasil uji lapangan adalah sebagai berikut.

$$
\begin{aligned}
\text { Persentase } & =\frac{\Sigma(\text { skor total })}{\mathrm{n} \times \text { bobot tertinggi }} \times 100 \% \\
& =\frac{574}{675} \times 100 \\
& =85,04 \%
\end{aligned}
$$

Hasil perhitungan di atas menunjukkan persentase hasil validasi $85,04 \%$ setelah dikonversi skala 5, persentase tingkat pencapaian tersebut berada pada tingkat kualifikasi sangat valid sehingga evaluasi pembelajaran dengan menggunakan rubrik tidak perlu direvisi dan rubrik yang dibuat efektif untuk digunakan.

\section{E. PENUTUP}

Fakta pembelajaran di lapangan terhadap pengembangan evaluasi pembelajaran dengan menggunakan rubrik setelah melalui tahapan pengenalan dan percobaan melakukan evaluasi kepada peserta didik dengan cara penilaian menggunakan rubrik, maka guru yang awalnya belum memahami tentang rubrik sekarang sudah paham tentang rubrik. Hal tersebut dapat dilihat dari perbedaan ratarata pretes dan postes, yaitu 52,2 dan 88,06 .

Kelayakan evaluasi pembelajaran dengan menggunakan rubrik berupa penilaian sikap spiritual, sikap sosial, pengetahuan dan keterampilan Telah diuji oleh 2 validator ahli materi dengan menghasilkan hasil validasi sebesar $94,28 \%$ dan 2 orang guru sebagai validator stakeholder dengan hasil validasi sebesar 95\% sehingga produk yang dikembangkan layak untuk digunakan.

Keefektifan evaluasi pembelajaran dengan menggunakan rubrik berupa penilaian sikap spiritual, sikap sosial, pengetahuan dan keterampilan telah dilakukan uji coba lapangan yang terdiri dari Uji kelompok kecil menghasilkan nilai $86,67 \%$ dan uji kelompok besar menghasilkan 85,04\%. Sehingga produk tersebut sangat efektif untuk digunakan.

\section{DAFTAR PUSTAKA}

Arifin, Z. (2017). Evaluasi Pembelajaran. Bandung: Remaja Rosdakarya.

Arikunto. (2005). Dasar-Dasar Evaluasi Pendidikan. Jakarta: Bumi Aksara.

Aryani, F., \& Hiltrimartin, C. (2014). Pengembangan LKS untuk Metode Penemuan Terbimbing pada Pembelajaran Matematika Kelas VIII di SMP Negeri 18 Palembang. Jurnal Pendidikan Matematika, 5(2). doi:10.22342/jpm.5.2.578.

Hidayat, S. (2013). Pengembangan Kurikulum Baru. Bandung: Remaja Rosdakarya.

Kristiantari, M. (2015). Analisis Kesiapan Guru Sekolah Dasar dalam Mengimplementasikan

Pembelajaran Tematik Integratif Menyongsong Kurikulum 2013.JPI (Jurnal Pendidikan Indonesia), 3(2). doi:10.23887/jpiundiksha.v3i2.4462

Majid, A. (2014). Pembelajaran Tematik Terpadu. Bandung: Remaja Rosdakarya.

Nurgiyantoro, B. (2012). Penilaian Pembelajaran Bahasa. Yogyakarta: Gadjah Mada University Press.

Purnamasari, A. \& Rochmawati. (2015). Pengembangan Alat Evaluasi Pembelajaran Berbasis Teknologi Informasi Dan Komunikasi Dengan Wondershare Quiz Creator Materi Sistem Penilaian Persediaan. Jurnal Pendidikan Akuntansi, 3(2). https://jurnalmahasiswa.unesa.ac.i d/index.php/jpak/article/view/13 175

Purwanto. (2010). Evaluasi Hasil Belajar. Yogyakarta: Pustaka Pelajar. 
Rustaman, Y. (2006). "Penilaian Otentik (Authentic Assessmen) dan Penerapannya dalam Pendidikan Sains.

http://file.upi.edu/Direktori/SPS/ PRODI.PENDIDIKAN_IPA/195 012311979032-

NURYANI_RUSTAMAN/PENI

LAIAN_OTENTIK_Sgr'06.pdf

Sugiyono. (2017). Metode Penelitian \& Pengembengan Research and Development. Bandung: Alfabeta.

Wangid, M., Mustadi, A., Erviana, V., \& Arifin, S. (2014). Kesiapan Guru SD dalam Pelaksanaan Pembelajaran Tematik-Integratif pada Kurikulum 2013 di DIY. Jurnal Prima Edukasia, 2(2), 175-182. doi:10.21831/jpe.v2i2.2717

Wirianto, D. (2014). Perspektif Historis Transformasi Kurikulum di Indonesia. Islamic Studies Journal, 2(1), 133-147. https://www.academia.edu/32791 019/Dicky_Wirianto_Perspektif_H istoris_Transformasi_Kurikulum_d i_Indonesia 